\title{
Studies in Ephesians
}

Edited by F. L. CROSS, D.D.

J. N. SAnders, Dean of Peterhouse, and Professor Ninkram respectively argue for and against Pauline authorship. The BISHOP of LaICESTER writes on 'The Pauline Catechesis', D. E. H. Whitrley on 'Christology', E. K. LeB on 'Unity in Israel and Unity in Christ', S. M. GrbBard on 'The Christian Mystery' (the Eucharist), S. F. B. Bedare on 'The Theology of the Church', and C. P. M. JonEs on 'The Calling of the Gentiles'.

\section{God and Us}

JEAN DANIELOU

Translated from the French of Dieu et Nous by Walter Roberts

The author has set himself in this book to examine all the different ways of approach to the knowledge of the Deity. He deals in succession with the God of the Religionists, the God of the Philosophers, and the God of the Christian faith. This completeness of perspective gives a special character to a learned work which has come to be regarded as an indispensable introduction to the subject on the Continent.

Forthcoming, 21s.

\section{Peter}

\section{A Paschal Liturgy}

Professor F. L. CROSS, D.D.

A new study of the Epistle from a liturgical and patristic angle. He traces a fascinating connection between this puzzling book and the celebration of Easter in the Early Church.

'The essay is a stimulating study of first-class importance.' Expository Times. 2nd Imp., 3s. $6 d$.

\section{MOW B R A Y S}

\section{NEW \\ TYNDALE \\ MONOGRAPHS}

\section{GOD BECAME MAN}

Some considerations of the questions How? and Why?

By the Rev. Alan M. Stibis, m.A. Is. $6 d$.

\section{SCRIPTURE AND MYTH}

An examination of Professor Rudolf Bultmann's plea for demythologization.

By the Rev. P. E. HugheS, M.A., B.D., D. LITT.

Is. $6 d$.

\section{THE TEACHER OF RIGHTEOUSNESS IN THE QUMRAN TEXTS}

By Professor F. F. BruCB, M.A. $2 s$.

\section{THE TYNDALE PRESS}

39 Bedford Square, London, W.C.I

\section{Colossians \& Philemon}

\section{EDITED BY \\ C. F. D. MOULE}

The first volume in a new series: The Cambridge Greek Testament Commentary under the General Editorship of Professor C. F. D. Moule. The series will reflect the present shift of emphasis in New Testament scholarship towards the theological and religious content.

2Is. net 


\section{New Testament Writings}

NEW TESTAMENT FAITH FOR TODAY AMOS N. WILDER, Professor of New Testament Interpretation at Harvard Divinity School, USA

I5s net

A skilful statement of a way to mediate the fruits of recent

biblical scholarship to modern man in his actual needs.

\section{THE STATE IN THE NEW TESTAMENT} oscar CullmanN, Professor of New Testament Studies at Basel and the Sorbonne

I2s $6 \mathrm{~d}$ net

A scholarly discussion of a modern problem seen in the light of the New Testament.

\section{STUDIES IN THE ACTS OF THE APOSTLES} MARTIN DIBELIUS, translated by Mary Ling

These studies range from the problems of the text to the literary allusions.

\section{THE EARLY CHURCH}

Historical and Theological Studies

oscar CULlmanN, edited by A. J. B. Higgins

25s net

This collection of writings and essays is intended to present outstanding examples of Professor Cullmann's contributions to varied aspects of early Church history and theology.

\section{Two new Studies in Biblical Theology}

\section{THE PROBLEM OF HISTORY IN MARK}

JAMES M. ROBInson, Associate Professor of Theology, Emory University, Georgia, USA

\section{ESSAYS ON TYPOLOGY}

G. W. H. LAMPE, Professor of Theology, University of Birmingham; к. J. Woollcombe, Fellow, Chaplain and Lecturer of St John's College, Oxford $7 \mathrm{~s} 6 \mathrm{~d}$ net

\section{SCM PRESS}

